\title{
Relation between exercise-induced pulmonary hemorrhage and findings in upper airway and trachea in Thoroughbred racehorses
}

Relação entre hemorragia

pulmonar induzida por exercício e observações em vias aéreas superiores e traqueia em equinos Puro Sangue Inglês

Universidade de São Paulo (USP), São Paulo, SP, Brazil

*Correspondence: tiagooliveira@usp.br

Received: 2021 Feb 5 | Approved: 2021 Apr 6

DOI: http://dx.doi.org/10.7213/acad.2021.19003

Rev. Acad. Ciênc. Anim. 2021;19:e19003

\section{Abstract}

This retrospective study aimed to investigate the relationship between exercise-induced pulmonary hemorrhage (EIPH) and upper airway disorders in Thoroughbred racehorses that competed at the São Paulo Jockey Club between 1999 and 2005. Data were collected from 4,036 endoscopic examinations performed $30 \mathrm{~min}$ after a race by the same examiner. The association between upper airway disorders and
Domingos Antonio Mucciacito Júnior (D) Luis Claudio Lopes Correa Silva (D) Tiago Marcelo Oliveira (D)
EIPH was assessed using the chi-square test. In total, 2299 and 1737 horses received and did not receive furosemide before a race, respectively. The incidence of EIPH in medicated and non-medicated horses was $52.4 \%$ and $60 \%$, respectively. Among horses with left-sided laryngeal hemiplegia or dorsal displacement of the soft palate, $61.0 \%$ and $64.1 \%$ of them had EIPH, respectively. There was no relationship between EIPH and other upper airway disorders, such as pharyngeal lymphoid hyperplasia and mucopurulent discharge draining from guttural pouch openings. Left-sided laryngeal hemiplegia and dorsal displacement of the soft palate were positively associated with EIPH, but the association was statistically significant only for dorsal displacement of the soft palate $(p<0,05)$.

Keywords: Dorsal displacement of the soft palate. Endoscopy. Horses. Left-sided laryngeal hemiplegia. Racehorses. 


\section{Resumo}

O objetivo desse estudo retrospectivo foi avaliar a correlação entre a hemorragia pulmonar induzida pelo exercício (HPIE) e alterações das vias aéreas superiores e achados em traqueia em equinos da raça Puro Sangue Inglês (PSI) que competiram no hipódromo de Cidade Jardim do Jockey Club de São Paulo no período de 1999 a 2005. Foram analisados 4036 laudos de exames endoscópicos, os quais eram realizados trinta minutos após a corrida e por um único examinador. As alterações em vias aéreas superiores foram comparadas com os achados de HPIE utilizando o teste do Qui-quadrado. Dos exames analisados, 2299 animais foram submetidos à medicação prévia com furosemida e 1737 não foram medicados. Os resultados obtidos com relação à incidência de HPIE no grupo de animais medicados e não medicados foram $52,4 \%$ e 60,0\%, respectivamente. Dos animais que apresentavam neuropatia laringeana recorrente esquerda ou deslocamento dorsal de palato mole, observou-se HPIE em $61,0 \%$ e $64,1 \%$ respectivamente. Nas demais alterações, como secreção mucopurulenta drenando pelo óstio faríngeo da bolsa gutural e hiperplasia folicular linfoide, não se observou relação com a HPIE. Conclui-se que a hemiplegia laringeana esquerda e o deslocamento dorsal do palato mole apresentaram relação positiva com a HPIE, sendo que apenas para a segunda foi estatisticamente significativa $(p<0,05)$.

Palavras-chave: Deslocamento dorsal do palato mole. Endoscopia. Cavalos. Hemiplegia laringeana idiopática. Cavalos de corrida.

\section{Introduction}

Exercise-induced pulmonary hemorrhage (EIPH) is characterized by the presence of blood in the pulmonary alveoli and airways, preventing gas exchange and, consequently, reducing lung efficiency. It is considered the most important cause of poor performance in athletic horses and is one of the most commonly treated medical conditions, leading to significant economic losses (Erickson, 2000; Birks et al., 2003; Hinchcliff et al., 2005; Morley et al., 2015); however, a previous study did not find any association between the grade of EIPH and the earnings obtained in the horse's career (Sullivan et al., 2015).
Several factors and pathophysiological mechanisms have been suggested as causes of pulmonary capillary rupture in EIPH, including exercise-induced blood hyperviscosity, continuous mechanical trauma induced by visceral impact during galloping, trauma by impact of the scapula on the chest wall during footfall, pulmonary hypertension, inflammatory lesions and airway obstruction (Pascoe, 1996; Roberts and Erickson, 1999; Schroter et al., 1999; Erickson, 2000). All these mechanisms may contribute to EIPH, but do not explain the fundamental cause of bleeding.

The occurrence of EIPH is common, and its severity may vary among horses as well as in EIPH episodes in the same animal (Preston et al., 2015). It has been shown that the rider interference causes upper airway instability increasing the risk of EIPH in show jumping horses (Van Erck, 2011; Bonomo et al., 2019). Many veterinarians consider that upper airway diseases and tracheal findings may influence the occurrence of EIPH, but no studies have demonstrated this relationship statistically. Therefore, this study aimed to investigate whether the occurrence of upper airway disorders and tracheal findings influences the incidence of EIPH, diagnosed using endoscopy after a race.

\section{Material and methods}

This study investigated files of endoscopic examinations of Thoroughbred racehorses referred to the Department of Veterinary Service (DAV) after official races at the São Paulo Jockey Club from March 1999 to September 2005, with special interest in the upper airways and trachea. A single examiner performed all endoscopies $30 \mathrm{~min}$ after the race, with the horse in a standing position under the restraint of a twitch. Sedatives were not used when performing examinations.

Horses were examined in three situations: (1) because they had previous authorization to be medicated with furosemide $(0.5 \mathrm{mg} / \mathrm{kg} \mathrm{IV);} \mathrm{(2)} \mathrm{when}$ they were not medicated but their performance was against expectation; or (3) the endoscopic examination after the race was a request of the responsible veterinarian. Then, as a purpose of the present study, endoscopic findings were compared between furosemide-medicated and non-medicated horses, with no distinction according to gender. 


\section{Endoscopic exam}

A flexible fiberscope connected to a halogen light source was used. Upper airways disorders and tracheal findings of mucus and blood were identified endoscopically and classified as follows:

- EIPH was graded using a system suggested by Hinchcliff et al. (2005). This system uses a five-level scale ranging from 0 (no blood) to 4 (blood covering $>90 \%$ of the tracheal surface);

- The presence of mucopurulent secretions draining from the pharyngeal ostium into the guttural pouch was a notified change in endoscopic reports. The routine endoscopic examination did not include an internal view of the guttural pouch. Occasionally, with the endoscope positioned in the pharyngeal region, it was possible to observe the opening of the pharyngeal ostium at the moment of swallowing. The presence of mucopurulent secretions in the trachea was considered and classified according to the amount and distribution of secretions along the trachea, according to the classification suggested by Greet (1982), using none $=0$, few flecks $=1$, small pool at thoracic inlet $=2$, large pool at and beyond the thoracic inlet $=3$.

The grade of pharynx inflammation was classified according to the classification suggested by Raker and Boles (1978); however, lymphoid follicular hyperplasia (LFH) grades 1 and 2 were not reported during endoscopic examination of horses aged $<4$ years as it is considered a normal finding at this age.

Intermittent dorsal displacement of the soft palate (DDSP) has been reported only for horses presenting an inability to replace the soft palate after dorsal displacement and/or with the presence of an ulcer in the mucosa of the free margin of the caudal soft palate.

The classification of the grade of left-sided laryngeal hemiplegia (LLH) concerning the movement of the left arytenoid cartilage was proposed by Hackett et al. (1991), and all grades of movement reduction were considered (I - IV).

\section{Statistical analysis}

The relationship between EIPH and upper airway and tracheal disorders was considered positive when the percentage of EIPH incidence in a sample was greater than the average incidence in the total sample, and it was considered negative when the percentage of the incidence of EIPH in the sample was less than the average incidence in the total sample. The data obtained were subjected to comparative statistical analysis using the chi-square test. The statistical results were considered highly significant when the $p$-value was $<0.01$, statistically significant when the $p$-value was $\leq 0.05$, and not statistically significant when the $p$-value was $>0.05$.

\section{Results and discussion}

The findings of 4,036 endoscopic examinations were analyzed. In total, examinations were performed for 2,382 male and 1,654 female horses. Furthermore, 2,299 horses (1,394 male and 905 female horses) received furosemide before a race, while 1,737 horses (988 male and 749 female horses) did not receive furosemide.

The number of male horses subjected to endoscopic examination was greater than that of female horses $(59.27 \%$ vs. $40.73 \%)$. This ratio was similar in the medicated and non-medicated groups (60.64\% male horses in the medicated group and $56.88 \%$ male horses in the non-medicated group). The higher percentage of males reflects the equine population of the São Paulo Jockey Club, probably due to the early use of females for reproduction, which ends their athletic careers sooner than males. However, only males with exceptional performance are selected to perform a reproductive function; therefore, the majority remain in the competition.

Considering all the examined horses, $55.80 \%$ of them showed some grade of EIPH. This result differs from that reported by Pascoe et al. (1981), that demonstrated the presence of EIPH in $43.80 \%$ Thoroughbred racehorses, including medicated and non-medicated horses. Sullivan et al. (2015) did not find association between grades $0,1,2$, and 3 of EIPH and the results obtained during the horses' careers. However, their evaluation consisted of an endoscopic examination at the beginning of the study, and the authors emphasized the importance of further studies on endoscopic monitoring of animals during their careers.

Considering the non-medicated, horses $60 \%$ evidenced blood in the tracheal lumen. In previous studies, the incidence of EIPH in non-medicated 
Thoroughbred populations without clinical signs or reduced performance ranged from 58 to $77 \%$ (Raphael and Soma, 1982; Eppinger, 1990; Da Nova, 2000; Hinchcliff et al., 2005). The lower incidence of EIPH was found in a study by MacNamara et al. (1990) conducted in New York; only 26\% racehorses were affected by EIPH. This can be credited to the criterion used to classify EIPH, that is, the presence of blood covering more than half of the tracheobronchial tree, which differs from the classification used in our study.

Considering the severity of EIPH in the total sample, grade 2 had the highest incidence $(20.44 \%)$, followed by grades 1 (19.23\%), 3 (8.08\%), and 4 (8.05\%). The EIPH grade described in the literature varies according to the scoring system used by the examiner. The EIPH grade in the non-medicated horses in this study was similar to that reported by Hillidge and Whitlock (1986). In a study by Da Nova et al. (2000), the incidence of EIPH grade 4 was $3 \%$, while in our study it was $14.80 \%$ in the nonmedicated animals. Hedegüs et al. (2007) used tracheal wash two hours after the race and identified reduction in hemosiderophages number and red blood cells count in EIPH-diagnosed horses treated with furosemide before the race, as well as Knych et al. (2018) found lower severity of EIPH in horses that received furosemide four hours before the exercise. In a study in Brazil, it was demonstrated that racehorses that did not show EIPH after using furosemide showed the best performances (Costa and Thomassian, 2006).

Upper airway and tracheal disorders occurred in $52.39 \%(2,114)$ horses, excluding those with EIPH and the presence of dirt in the tracheal mucosa. The incidence of upper airway and tracheal disorders varies widely in the literature, ranging from 3.7 to 65\% (Pascoe et al., 1981; Raphael and Soma, 1982; Sweeney, 1991; Hinchcliff et al., 2005; LagunaLegorreta, 2006). It is important to emphasize that the presence or absence of clinical signs and the criteria of measurements used for these studies interfere with the results. This is probably the main reason for the significant difference between the results reported.

Laguna-Legorreta (2006) found that 64.95\% Thoroughbred horses with or without clinical signs had airway disorders. Sweeney et al. (1991) showed that only $3.7 \%$ Thoroughbred horses without clinical manifestations presented changes in the upper airway; however, this study excluded LFH and the presence of tracheal mucopurulent secretion. In a similar study, Pascoe et al. (1981) found that $8.10 \%$ horses without clinical signs presented upper airway disorders, and Brown et al. (2005) found that 6.30\% horses presented upper airway disorders.

LFH occurred in $47.60 \%$ horses and showed no positive relationship with EIPH. The incidence of $\mathrm{LFH}$ varies according to the criteria used to assess the severity of laryngeal inflammation in the sample. The incidence of LFH ranges from 29.30\% (without clinical manifestations) to $97.00 \%$ (including clinical manifestations) (Auer et al., 1985; Raphael and Soma, 1982).

The incidence of mucopurulent secretions draining from the pharyngeal ostium into the guttural pouches was $7.30 \%$, which is similar to that reported by MacNamara et al. (1990). A higher incidence (19\%) of mucopurulent secretions was found by LagunaLegorreta (2006) in a study of animals with and without clinical signs. In our study, there was no positive relationship between the presence of mucopurulent secretions draining from the pharyngeal ostium into the guttural pouches and EIPH.

The presence of mucopurulent secretions in the trachea was $39.8 \%$ in our study, and there was a negative correlation between the presence of secretions and EIPH $(p<0.01)$, which is consistent with findings of a study by Lapointe et al. (1994). Inadequate alveolar ventilation caused by inflammatory disease of the airways can be a possible cause of EIPH (Robinson and Derksen, 1980), however, the absence of an association between EIPH and mucopurulent secretions found in these studies does not favor this hypothesis.

Intermittent DDSP was present on $4.20 \%$ horses in this study. The incidence of EIPH associated with intermittent DDSP was $64.12 \%$, which was greater than that overall incidence of EIPH observed in the total sample (55.80\%). The percentage of animals with EIPH grade 4 who presented DDSP was $4.71 \%$, which was lower than that of animals with an EIPH grade 4 in the total sample $(8.05 \%)$; however, a greater occurrence of DDSP in EIPH grade 2 (32.94\%) and $3(9.41 \%)$ was noted compared to the total sample (20.44\% and $8.08 \%$, respectively) (Figure 1). The horses affected by intermittent DDSP presented a significant positive relationship with EIPH compared to horses in the total sample $(p<0.05)$. 


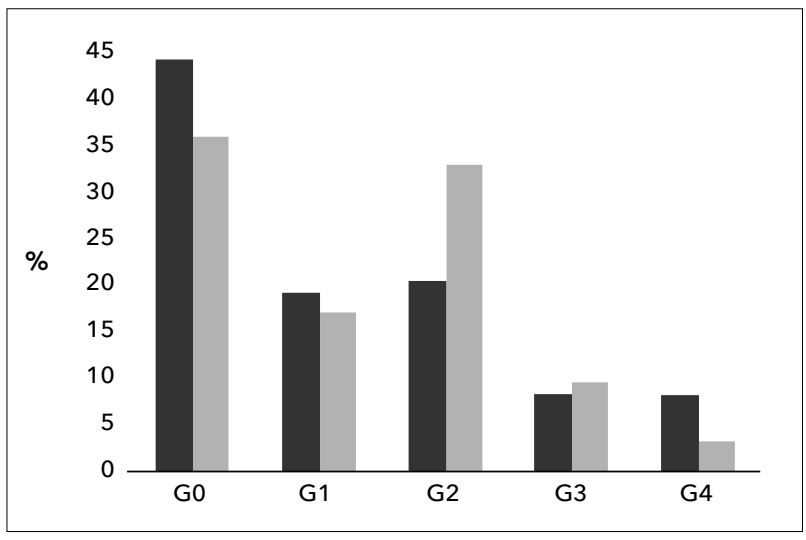

Figure 1 - Black bars: occurrence of exercise-induced pulmonary hemorrhage (EIPH) in the total sample, grade 0-4 (G0 - G4); Gray bars: distribution of horses with dorsal displacement of the soft palate (DDSP) associated with grade 0 - $4 \mathrm{EIPH}$.

The incidence of intermittent DDSP in the literature ranges from 0.5 to $33 \%$ (Raphael and Soma, 1982; MacNamara et al., 1990; Hobo et al., 1995; Brown et al., 2005). This high variation may be due to the different diagnostic criteria adopted by the studies. In our study, the relationship between DDSP and EIPH $(p<0.05)$ was noted when considering animals that showed an inability to replace the soft palate after dorsal displacement and/or the presence of an ulcer in the mucosa of the free margin of the caudal soft palate when shifted, which may explain the lower incidence of DDSP in our study than that reported in other studies. Since DDSP is considered an obstructive disease, which may favor the appearance of EIPH, it is believed that this result reinforces the relationship between these two diseases.

The percentage of animals affected by LLH was $6.86 \%$. The incidence of LLH-associated EIPH was $61.03 \%$, which was greater than that observed in the total sample (55.80\%). The percentage of EIPH grade 4 in horses with LLH (4.41\%) was lower than that in the total sample (8.05\%). However, there were greater percentages of EIPH grade 2 (26.84\%) and 3 (10.29\%) when compared to the total sample $(20.44 \%$ and $8.08 \%$, respectively). The index of EIPH grade 1 was similar to that of the total sample (Figure 2). Although the results did not show statistical significance ( $p>0.05$ ), the horses affected by LLH showed a relationship with the EIPH.

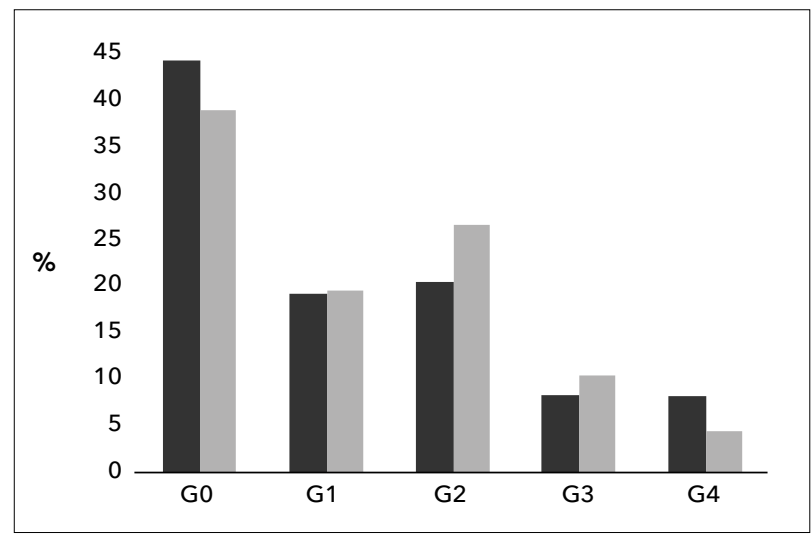

Figure 2 - Black bars: occurrence of exercise-induced pulmonary hemorrhage (EIPH) in the total sample, grade 0 - 4 (G0 - G4); Gray bars: distribution of horses observed with left-sided laryngeal hemiplegia (LLH) associated with grade 0 - $4 \mathrm{EIPH}$.

Raphael and Soma (1982) found LLH in nine horses examined after a race, and eight of them presented EIPH. Sweeney (1991) found LLH in 12 horses, of which eight horses presented EIPH. In both studies, the statistical analysis of the data showed no association between LLH and EIPH. These studies corroborate the hypothesis proposed by Cock et al. (1988), which suggested a positive relationship between EIPH and LLH, however, without statistical proof.

Our data corroborate the findings of other studies that found a variation of $2.60-8.30 \%$ in the incidence of LLH in the equine population (Pascoe et al., 1981; Hillidge and Witlock, 1986). In training horses that were presenting clinical demonstrations of cough and abnormal respiratory noises, Hobo et al. (1995) reported the presence of LLH in $67.70 \%$ of the population of 350 Thoroughbreds. Goulden and Anderson (1981) reported that 45\% Thoroughbred horses without specific clinical demonstrations presented laryngeal asynchrony, a much higher value than that found in our study. Laguna-Legorreta (2006) noted that $16.65 \%$ Thoroughbred horses presented LLH. Of those, $39 \%$ had grade $1 \mathrm{LLH}, 37 \%$ had grade $2,15 \%$ had grade 3 , and $9 \%$ had grade 4 . In our study, $29 \%$ horses had grade $1 \mathrm{LLH}, 37 \%$ had grade $2,13.40 \%$ had grade 3 , and $20.60 \%$ had grade 4 . The reason for the great variation in the incidence of LLH can be attributed to the sampling of the examined horses, criterion of diagnosis, and timing of when the horses were evaluated (Brown et al., 2005). 


\section{Conclusion}

Among the identified upper airway and tracheal disorders, only the dorsal displacement of the soft palate and LLH presented a positive relationship with $\mathrm{EIPH}$, and only the former relationship was statistically significant. EIPH grade 4 did not have a positive relationship with any of the identified upper airway and tracheal disorders.

\section{References}

Auer DE, Wilson RG, Groenendyk S. Pharingeal lymphoid hyperplasia in Thoroughbred racehorses in training. Aust Vet J. 1985;62(4):124-6.

Birks EK, Durando MM, McBride S. Exercise-induced pulmonary hemorrhage. Vet Clin North Am Equine Pract. 2003;19(1):87-100.

Bonomo CCM, Michelotto PV, Viccino C, Barussi FCM, Fernandes WR. Occurrence of exercise-induced pulmonar haemorrhage in show jumping horses. Vet J. 2019;248:91-4.

Brown JA, Hinchcliff KW, Jackson MA, Dredge AF, O'Callaghan RA, McCaffrey JR, et al. Prevalence of pharyngeal abnormalities in Thoroughbreds racing in Australia, and their association with performance. Equine Vet J. 2005;37(5):397-401.

Cock WR, Williams RM, Kirker-Head CA, Verbridge DJ. Upper airway (partial asphyxia) as the possible cause of exerciseinduced pulmonary hemorrhage in the horse: An hypothesis. $J$ Equine Vet Sci. 1988;8(1):11-26.

Costa MFM, Thomassian A. Evaluation of race distance, track surface and season of the year on exercise-induced pulmonary haemorrhage in flat racing Thoroughbreds in Brazil. Equine Vet J Suppl. 2006;(36):487-9.

Da Nova CAB, Amaral PC, Pitombo CAP, Ribeiro LCG. Ocorrência da hemorragia pulmonar induzida pelo esforço (HPIE) no Jockey Clube Brasileiro (Rio de Janeiro). In: Proceedings of the Conferência Sul-Americana De Medicina Veterinária, Rio de Janeiro, RJ; 2000. p. 228.

Eppinger M. Hemorragia pulmonar do esforço e o desempenho de equinos PSI em corridas de galope no Jockey Club do Paraná [master's thesis]. Curitiba: Universidade Federal do Paraná; 1990. 167 p.
Erickson $\mathrm{HH}$. A review of exercise-induced pulmonary hemorrhage and new concepts for prevention. In: Proceedings of the Annual Convention America Association of Equine Practitioners. 2000;46:193-6.

Goulden BE, Anderson LJ. Equine laryngeal hemiplegia part II: Some clinical observations. N Z Vet J. 1981;29(11):194-8.

Greet TR. Collection of tracheal aspirates in horses. In Pract. $1982 ; 4(5): 148$.

Hackett RP, Ducharme NG, Fubini SL, Erb HN. The reliability of endoscopic examination in assessment of arytenoid cartilage movement in horses. Part I: Subjective and objective laryngeal evaluation. Vet Surg. 1991;20(3):174-9.

Hegedüs RM, Michima LES, Souza VRC, Dutra GHP, Fernandes WR, Coelho CS. Evaluation of tracheal wash of horses with exercise-induced pulmonary hemorrhage treated with furosemide. Arq Bras Med Vet Zootec. 2007;59(2):527-9.

Hillidge CJ, Whitlock TW. Sex variation in the prevalence of exercise-induced pulmonary hemorrhage in racing Quarter Horses. Res Vet Sci. 1986;40(3):406-7.

Hinchcliff KW, Jackson MA, Brown JA, Dredge AF, O'Callaghan PA, McCaffrey, JP, et al. Tracheobronchoscopic assessment of exercise-induced pulmonary in Thoroughbred horses. Am J Vet Res. 2005;66(4):596-8.

Hobo S, Matsuda Y, Yoshida K. Prevalence of upper respiratory tract disorders detected with a flexible video endoscope in Thoroughbred racehorses. J Vet Med Sci. 1995;57(3):409-13.

Knych HK, Wilson WD, Vale A, Kass PH, Arthur RM, Jones JH. Effectiveness of furosemide in attenuating exercise-induced pulmonary haemorrhage in horses when administered at 4- and 24-h prior to high-speed training. Equine Vet J. 2018;50(3):350-5.

Laguna-Legorreta GG. Estudo analítico das endoscopias das doenças das vias aéreas de equinos PSI durante o período de 1993 - 2003 e avaliação dos resultados de procedimentos cirúrgicos laringeanos realizado no Jockey Club de São Paulo durante o período de 1998-2003 [dissertation]. Botucatu: UNESP; 2006.

Lapointe JM, Vrins A, McCarvill E. A survey of exercise-induced pulmonary hemorrhage in Quebec Standardbred racehorses. Equine Vet J. 1994;26(6):482-5. 
MacNamara B, Bauer S, lafe J. Endoscopic evaluation of exerciseinduced pulmonary hemorrhage and chronic obstructive pulmonary disease in association with poor performance in racing Standardbreds. J Am Vet Med Assoc. 1990;196(3):443-5.

Morley PS, Bromberek JL, Saulez MN, Hinchcliff KW, Guthrie AJ. Exercise-induced pulmonary hemorrhage impairs racing performance in Thoroughbred racehorses. Equine Vet J. 2015;47(3):358-65.

Pascoe JR. Exercise-induced pulmonary hemorrhage: a unifying concept. In: Proceedings of the Annual Convention American Association of Equine Practitioners. 1996;42:220-6.

Pascoe JR, Ferraro GL, Cannon JH, Arthur RM, Wheat JD. Exerciseinduced pulmonary hemorrhage in racing Thoroughbreds: a preliminary study. Am J Vet Res. 1981;42(5):703-7.

Preston SA, Riggs CM, Singleton MD, Troedsson MHT. Descriptive analysis of longitudinal endoscopy for exerciseinduced pulmonary haemorrhage in Thoroughbred racehorses training and racing at the Hong Kong Jockey Club. Equine Vet J. 2015;47(3):366-71

Raker CW, Boles CL. Pharyngeal lymphoid hyperplasia in the horse. J Equine Med Surg. 1978;2:202-7.

Raphael CF, Soma LR. Exercise-induced pulmonary hemorrhage in Thoroughbreds after racing and breeding. Am J Vet Res. 1982;43:1123-7.
Roberts CA, Erickson HH. Exercise-induced pulmonary hemorrhage workshop. Equine Vet J Suppl. 1999;(30):642-4.

Robinson NE, Derksen FJ. Small airway obstruction as cause of exercise associated pulmonary hemorrhage: an hypothesis. In: Proceedings American Association of Equine Practitioners. 1980;26:421-30.

Schroter RC, Leeming A, Denny E, Bharath A, Marlin DJ. Modelling impact-initiated wave transmission through lung parenchyma in relation to the aetiology of exercise-induced pulmonary haemorrhage. Equine Vet J Suppl. 1999;(30):34-8.

Sweeney CR. Exercise-induced pulmonary hemorrhage. Vet Clin North Am Equine Pract. 1991;7(1):93-104.

Sullivan SL, Anderson GA, Morley PS, Hinchcliff KW. Prospective study of the association between exercise-induced pulmonary haemorrhage and long-term performance in Thoroughbred racehorses. Equine Vet J. 2015;47(3):350-7.

Van Erck E. Dynamic respiratory videoendoscopy in ridden sport horses: effect of head flexion, riding and airway inflammation in 129 cases. Equine Vet J Suppl. 2011;(40): 18-24. 